\title{
UV-induced carbon monoxide emission from sand and living vegetation
}

\author{
Bruhn, Dan; Albert, Kristian Rost; Mikkelsen, Teis Nørgaard; Ambus, Per
}

Published in:

Biogeosciences Discussions

Link to article, DOI:

10.5194/bgd-9-8449-2012

Publication date:

2012

Document Version

Publisher's PDF, also known as Version of record

Link back to DTU Orbit

Citation (APA):

Bruhn, D., Albert, K. R., Mikkelsen, T. N., \& Ambus, P. (2012). UV-induced carbon monoxide emission from sand and living vegetation. Biogeosciences Discussions, 9(7), 8449. https://doi.org/10.5194/bgd-9-8449-2012

\section{General rights}

Copyright and moral rights for the publications made accessible in the public portal are retained by the authors and/or other copyright owners and it is a condition of accessing publications that users recognise and abide by the legal requirements associated with these rights.

- Users may download and print one copy of any publication from the public portal for the purpose of private study or research.

- You may not further distribute the material or use it for any profit-making activity or commercial gain

- You may freely distribute the URL identifying the publication in the public portal

If you believe that this document breaches copyright please contact us providing details, and we will remove access to the work immediately and investigate your claim 


\section{UV-induced carbon monoxide emission from sand and living vegetation}

D. Bruhn, K. R. Albert, T. N. Mikkelsen, and P. Ambus

Department of Chemical and Biochemical Engineering, Technical University of Denmark (DTU), 2800 Kgs. Lyngby, Denmark

Received: 14 June 2012 - Accepted: 25 June 2012 - Published: 17 July 2012

Correspondence to: D. Bruhn (dabr@kt.dtu.dk), (danbruhn10@gmail.com)

Published by Copernicus Publications on behalf of the European Geosciences Union.

\section{UV-induced carbon monoxide emission from sand and living vegetation \\ D. Bruhn et al.}

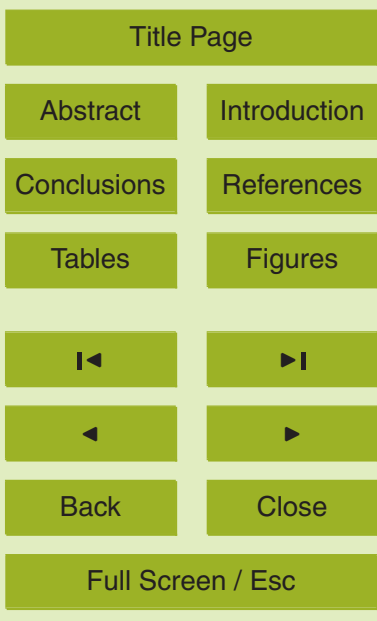

Printer-friendly Version

Interactive Discussion 


\section{Abstract}

The global burden of carbon monoxide, $\mathrm{CO}$, is rather uncertain. In this paper we address the potential of UV-induced CO emission by terrestrial surfaces. Real-time measurements of [CO] were made with a cavity enhanced laser connected in closed loop 5 to either an ecosystem chamber or a leaf scale chamber. Sand and leaves of all examined plant species exhibited emission of $\mathrm{CO}$ in response to artificial UV-radiation and the UV-component of natural solar radiation. The UV-induced rate of $\mathrm{CO}$ emission exhibited a rather low dependence on temperature, indicating an abiotic process. The emission of $\mathrm{CO}$ in response to the UV-component of natural solar radiation was also evident at the ecosystem scale. When scaled to the global level, the UV-induced emission of $\mathrm{CO}$ by the major types of terrestrial surfaces, living leaves and soil (here represented by sand), amounts up to $28 \mathrm{Tgyr}^{-1}$. This source has till now not been accounted for by IPCC, but is equivalent to $14-56 \%$ of the $50-200 \mathrm{Tgyr}^{-1}$ from sources currently accounted for (IPCC 2001). In addition to this are other known sources that ought to be considered. The hitherto unaccounted for terrestrial sources of $\mathrm{CO}$ amounts up to $207 \mathrm{Tg} \mathrm{yr}^{-1}$, almost two-thirds of the latest estimated global CO burden of $360 \mathrm{Tg} \mathrm{yr}^{-1}$ (IPCC, 2001).

\section{Introduction}

Carbon monoxide (CO) is a reactive gas and the oxidizing capacity of the atmosphere is controlled largely by levels of CO (Potter et al., 1996). Carbon monoxide can lead to the formation of $\mathrm{O}_{3}$ and $\mathrm{CO}$ is the main reactant of $\mathrm{OH}$ radicals, why $\mathrm{CO}$ also indirectly affects the atmospheric $\mathrm{CH}_{4}$ levels (IPCC, 2001). Carbon monoxide is therefore an important trace gas in the atmosphere (Schade et al., 1999). Estimated total global source strengths and estimated total sink strengths are very similar (IPCC, 2001). Therefore, major uncertainty about one source or sink may potentially greatly influence the estimated net burden of $\mathrm{CO}$. Indeed, large uncertainties remain about the strength of the

\section{BGD}

9, 8449-8473, 2012

UV-induced carbon monoxide emission

from sand and living vegetation

D. Bruhn et al.

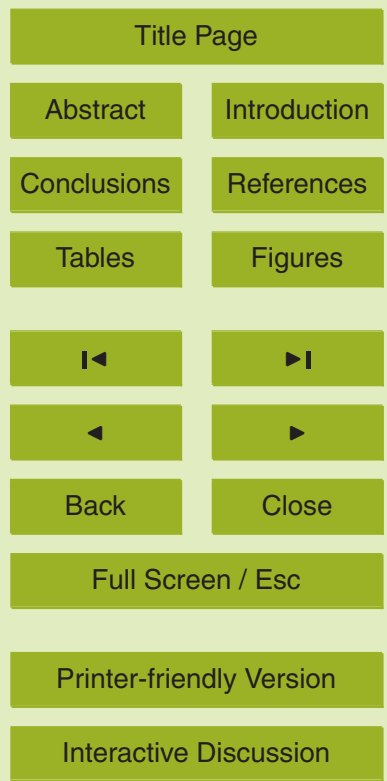


individual natural terrestrial direct sources in the global budget of $\mathrm{CO}$ (Potter et al., 1996; Guenther, 2002).

All natural terrestrial direct $\mathrm{CO}$ emission, 50-200 $\mathrm{Tg} \mathrm{yr}^{-1}$, has hitherto been ascribed by IPCC $(1995,2001)$ to photo-induced CO emission by living plants (cf. Tarr et al., 5 1995). However, other known sources ought to be considered. Firstly, a number of studies demonstrate up to ten times higher photo-chemically induced emission rates of $\mathrm{CO}$ by dead plant materiel (litter) compared to that of living plant material (Tarr et al., 1995; Yonemura et al., 1999). Emission of CO from plant litter has been estimated to contribute with 50-170 Tg yr$^{-1}$ globally (Tarr et al., 1995; Schade and Crutzen, 1999).

10 Secondly, a number of studies (cf. Potter et al., 1996) demonstrate a chemical oxidation, independent of photo-regulation, of decaying soil organic matter (SOM). This source has been estimated to contribute with 9.4 $\mathrm{Tg} \mathrm{yr}^{-1}$ (Potter et al., 1996).

In studies of photo-chemically induced release of $\mathrm{CO}$ by dead plant material, it was demonstrated that the more energy-rich UV played a very important part of the total CO emission (Tarr et al., 1995; Schade et al., 1999; Derendorp et al., 2011). However, in the studies underlying the photo-induced $\mathrm{CO}$ emission by living plants, which was incorporated in previous global CO budgets (IPCC, 1995, 2001), the UV-component of (sun)-light was not considered (Seiler and Giehl, 1977; Seiler et al., 1978). In this study, we examine the potential of UV-induced CO-emission from (i) sand (low in SOM) and from (ii) living plants. We did this experimentally under controlled laboratory conditions and under in situ field conditions; achieved data were extrapolated to global estimates.

\section{Materials and methods}

\subsection{Plant and sand material}

Leaves were freshly excised from well watered plants grown in pots in the greenhouse (Brassica oleracea capitata $f$. alba, Ficus elastica, Zea mays), from trees (Acer platanoides, Corylus avellana) and grasses growing in the near vicinity of the lab

UV-induced carbon monoxide emission from sand and living vegetation

D. Bruhn et al.

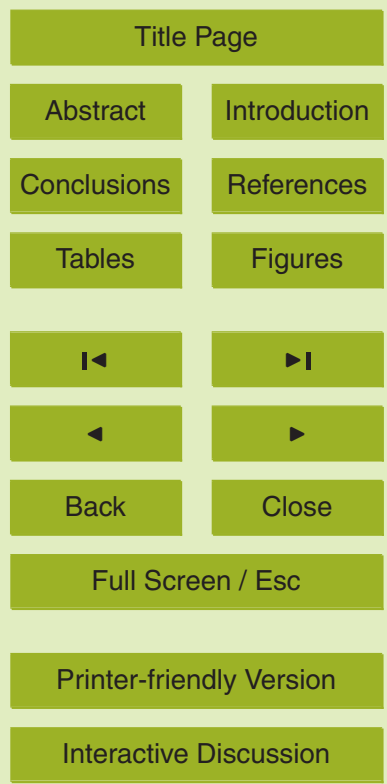


(dominated by Deschampsia flexuosa and with minor occurrence of Achilla millefolium and Plantago lanceolata). The grass field was on a sandy loam soil and received no fertilizer or other chemical treatment. The sand was washed quartz sand.

\subsection{Measurement system}

5 Real-time measurements of [CO], corrected for $\left[\mathrm{H}_{2} \mathrm{O}\right]$ interference, were conducted by off-axis enhanced cavity spectroscopy (Los Gatos $\mathrm{N}_{2} \mathrm{O}$ /CO analyzer, LGR Inc, Mountain View, CA, USA) connected to either an ecosystem Plexiglas chamber or a leaf scale Walz chamber (3010-GWK1, Heinz Walz GmbH, Effeltrich, Germany).

\subsubsection{Ecosystem-atmosphere $\mathrm{CO}$ exchange}

10 Ecosystem-atmosphere $\mathrm{CO}$ exchange measurements in situ on natural vegetation and sand and under ambient UV-B conditions, were conducted in September and October 2011 at DTU Ris $\varnothing$ campus $\left(55^{\circ} 41^{\prime} \mathrm{N}, 12^{\circ} 05^{\prime} \mathrm{E}\right)$. A UV-transparent Plexiglas chamber $\left(45 \times 45 \times 25 \mathrm{~cm}^{3}\right.$; PAR transmission $83 \%$; UV-B transmission $91 \%$ incl. water condensation on inside of chamber walls) was placed on a stainless steel collar pushed into the ground. A water-filled groove on top of the collar ensured a gas-tight seal between collar and chamber. The chamber was equipped with an internal fan to insure mixing and thermocouples measuring air temperature. For excluding solar UV-radiation in some experiments a larger UV-opaque chamber $\left(60 \times 60 \times 85 \mathrm{~cm}^{3}\right.$, transmitting only $32 \%$ UV-B, but $96 \%$ PAR) was placed on top of the ecosystem chamber. Photosynthetic active radiation (PAR; $400-700 \mathrm{~nm}$ ) and UV-B $(280-315 \mathrm{~nm}$ ) was measured next to the chamber with a LiCor LI-250A Light Meter and Gigahertz-Optik UV-1102 detector, respectively. No own $\mathrm{CO}$ contribution from the Plexiglass chamber could be detected. For measurements on sand a ca. $10 \mathrm{~cm}$ deep layer was placed inside the steel collar on top of a PTFE-film.

\section{BGD}

9, 8449-8473, 2012

UV-induced carbon monoxide emission from sand and living vegetation

D. Bruhn et al.

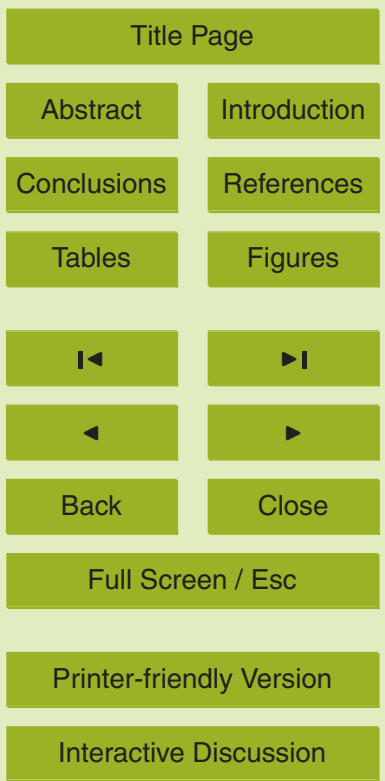




\subsubsection{Exchange of $\mathrm{CO}$ by leaves and samples of sand}

A temperature controlled and well mixed Walz leaf chamber with a UV-transparent quartz-glass lid was used. For light measurements, the lid was fitted with varying size of apertures to ensure that only the sample of interest inside the chamber re5 ceived light. For sun exposure, the chamber was placed outside the lab. For artificial UV exposure, lamps were positioned at varying distances to the lit of the chamber in the lab (see Bruhn et al., 2009). For dark measurements the entire lid was covered with layers of black cloth. A UV-opaque filter (transmitting only $17 \%$ of UV-B, but $91 \%$ of PAR) was used to examine the UV-effect. The Walz chamber release of $\mathrm{CO}$ was characterized in the laboratory in relation to chamber temperature $(T)$ as $0.15 \times 10^{-6} \times \mathrm{e}^{0.05 T} \mathrm{nmolCO} \mathrm{m}^{-2} \mathrm{~h}^{-1}$ and this value was subtracted from all calculations of CO mission rates (ER). Leaf samples were ca. 100 to $225 \mathrm{~cm}^{2}$ and sand samples were $50 \mathrm{~cm}^{2}$.

\subsubsection{Calculation of exchange rates}

15 The exchange of $\mathrm{CO}$ between the surface and atmosphere was calculated based on the changes in chamber $\mathrm{CO}$ concentration. A steady $\mathrm{CO}$ concentration change was commonly observed $\left(R^{2}>0.95\right)$ within time-windows of minimum $10 \mathrm{~min}$, and rates were derived from linear extrapolations.

\subsection{Estimating the global $\mathrm{CO}$ contribution}

20

Global up-scaling was based on the parameterized response equations to UV-B and temperature (see Sect. 3) and driven by geospatial satellite information on UV-B temperature and land surface classifications derived from normalized difference vegetation index (NDVI) and snow cover (SC). The $U_{310 \mathrm{~nm}}$ data was obtained from the Giovanni OMI/Aura Online Visualization and Analysis Daily Level 3 Global Grid-

\section{BGD}

9, 8449-8473, 2012

UV-induced carbon monoxide emission

from sand and living vegetation

D. Bruhn et al.

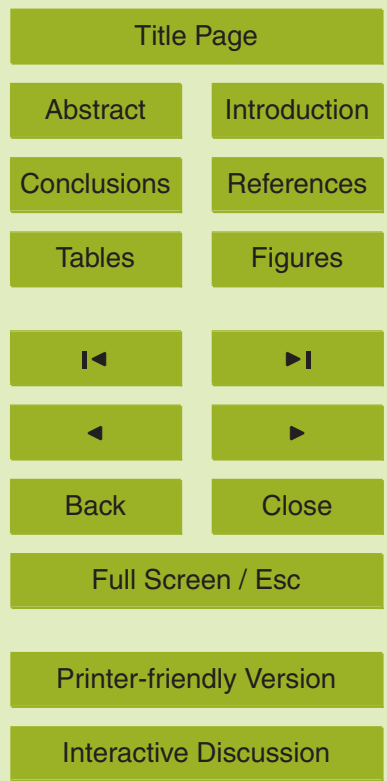


the temperature data from MODIS (Moderate Resolution Imaging Spectroradiometer, NASA Earth Observations, http://neo.sci.gsfc.nasa.gov) and NDVI, LAI, and SC data from NASA Earth Observations (http://neo.sci.gsfc.nasa.gov/) and handled in a global longitude/latitude grid $(250 \times 150)$.

5 The effect of UV was scaled with the global UV Irradiance at $310 \mathrm{~nm}$ (averaged across the years 2005, 2007, 2009, Local Noon Time Surface). Temperature dependence was scaled based on daytime land surface temperatures averaged per month (over the ten years 2001-2010) of available data. The temperature response parameterization did not include temperatures below $0{ }^{\circ} \mathrm{C}$, why the $\mathrm{CO}$ emission from grids with a temperature below $0^{\circ} \mathrm{C}$ were set to zero in the up-scaling.

Land surface area was determined from satellite land dataset information and the area was calculated from longitude latitude information. Snow cover (SC) was averaged per month (2009) and we excluded the areas covered by snow because the response equations were not tested on snow or ice. The remaining land surface area was classi-

fied as being vegetation covered or vegetation free based on the NDVI. The up-scaling approach was conservative in the way that the surface area did not include topography. Further, most of the UV-radiation received by leaf surfaces is indeed screened (absorbed or reflected) by the surface wax (Cen and Bornman, 1993; Liakoura et al., 2003; Jacobs et al., 2007). Therefore, for the global estimate of the UV-effect on CO emission by vegetation was assuming an effective Leaf Area Index (LAI) of unity. The proportions of vegetation and sand area were determined by NDVI classification. Response functions for plants were applied to surface covered by vegetation while sand response functions were applied to vegetation free surfaces.

The NDVI were averaged per month (2009). Correlations between LAI satellite measurement and NDVI from 2099 showed e.g. NDVI around 0.3, 0.5, 0.7 and 0.75 reflects vegetation with $0.4,0.9,2.0$ and 4.0 layers of leaves per ground area (LAI), respectively (data not shown). This information was used to construct four groups with different distributions among vegetation and vegetation free (sand) surfaces. The groups are: (1) NDVI $<0.2,100 \%$ sand. (2) $0.2<\mathrm{NDVI}<0.4,60 \%$ sand and $40 \%$ vegetation.

BGD

9, 8449-8473, 2012

UV-induced carbon monoxide emission from sand and living vegetation

D. Bruhn et al.

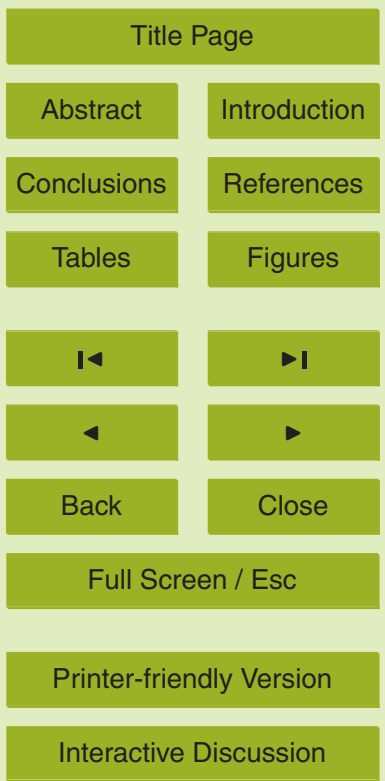


(3) $0.4<\mathrm{NDVI}<0.6,20 \%$ sand and $80 \%$ vegetation. (4) NDVI $>0.6,100 \%$ vegetation. These vegetation cover values are lower than a derivation from the NDVI LAI relationship would demand, but since vegetation cover is clustered by nature with LAI up to over 5 , this must results in more vegetation free areas than an average estimate would 5 produce. For the up-scaling any LAI above 1 would give the same values. This division into group categories decides the percentage area of vegetation and vegetation-free combination in each of the $250 \times 150$ grid cells.

\section{Results and discussion}

\subsection{Ecosystem-atmosphere CO exchange}

\subsubsection{Darkness}

When darkened, the grass field ecosystem was a significant sink for atmospheric CO (Fig. 1). Also, the pure sand reduced atmospheric $\mathrm{CO}$ when darkened (Fig. 1), however at a much lower rate. The measured uptake rate of $\mathrm{CO}$ can be approximated as the product of the $\mathrm{CO}$ diffusion coefficient of the top soil and $\mathrm{CO}$ concentration profile in the top soil profile (Potter et al., 1996) according to Fick's first law. Therefore, the difference in CO uptake rates between the grass field and $100 \%$ sand is in agreement with the expectation of a much more active microbial community in the grass rhizosphere compared to that of $100 \%$ sand due to microbial oxidation of CO (Potter et al., 1996; King and Weber, 2007). It is well known that soils take up CO (Potter et al., 1996) and 20 this sink has been estimated about $150 \mathrm{Tgyr}^{-1}$ globally (Khalil and Rasmussen, 1990). In fact, the gross uptake by soils rich in organic matter is expected to be higher than the typically reported and up scaled net rates of darkened of soils. This is because of a chemical (light independent) oxidation of organic soil matter, which globally amounts to about $9 \mathrm{Tgyr}^{-1}$ (Potter et al, 1996).
BGD

9, 8449-8473, 2012

UV-induced carbon monoxide emission from sand and living vegetation

D. Bruhn et al.

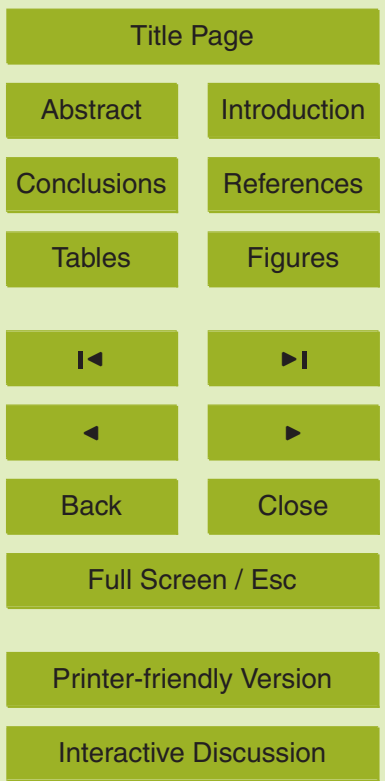




\subsubsection{Natural sunlight}

In response to natural sun-light the grass field exhibited a net CO release of $1628 \pm 309$ (mean $\pm \mathrm{SE}, n=27$, measurements in four plots) $\mathrm{nmolh}^{-1} \mathrm{~m}^{-2}$, whereas the $100 \%$ sand exhibited a net uptake of $422 \pm 84$ (mean \pm SE, $n=7$, measurements in three 5 plots) $\mathrm{nmol} \mathrm{CO} \mathrm{h} \mathrm{m}^{-1}$ (Fig. 1). For both types of surfaces a photo-induced gross release rate of $\mathrm{CO}$ can be calculated as the difference between the rates measured in natural sun-light and the rate in darkness, equal to $4437 \pm 464 \mathrm{nmol} \mathrm{CO} \mathrm{h}^{-1} \mathrm{~m}^{-2}$ and $293 \pm 183 \mathrm{nmolCO}^{-1} \mathrm{~m}^{-2}$ for the grass field and the $100 \%$ sand, respectively.

The calculated photo-induced positive gross release rate of $\mathrm{CO}$ from the grass field 10 very likely has its origin in the living vegetation. Firstly, the ground was fully covered with green grass leaves and therefore no exposure of the soil and secondly, the gross release rate of $\mathrm{CO}$ from the grass field is similar to that of excised grass leaves (Fig. 2, Sect. 3.2). Photo-induced $\mathrm{CO}$ emission from living plants has long been recognized and has been estimated to contribute globally with 50-200 $\mathrm{Tg} \mathrm{yr}^{-1}$ (Tarr et al., 1995).

15 Importantly, though, this global estimate is based solely on studies regarding the visible part $(400-700 \mathrm{~nm})$ of the solar spectrum as the potential effects of shorter wavelengths were not a part of the underlying experimental studies (Seiler and Giehl, 1977; Seiler et al., 1978). Till date no other studies have explicitly examined the potential of CO emission from living vegetation in response to the full natural spectrum of sunlight. However, a recent study by Galbally et al. (2010) of soil-atmosphere CO exchange in a semiarid Eucalyptus sp. ecosystem was conducted with chambers exposed to natural sunlight, although the transparent area of chamber construction as well as potential discrimination of certain wavelengths was somewhat unspecified. In that study Galbally et al. reported CO release (net) rates of ca. $3000 \mathrm{nmolh}^{-1} \mathrm{~m}^{-2}$ in the Eucalyptus sp. ecosystem. Even though the authors ascribe the $\mathrm{CO}$ release to predominantly origin in the organic soil and plant litter (Eucalyptus sp.) it is noteworthy that the Eucalyptus sp. ecosystem had a $50 \%$ leaf cover and furthermore the ground was covered with lichens and mosses. Thus, it is may be speculated that a substantial part of the measured CO

\section{UV-induced carbon monoxide emission from sand and living vegetation}

D. Bruhn et al.

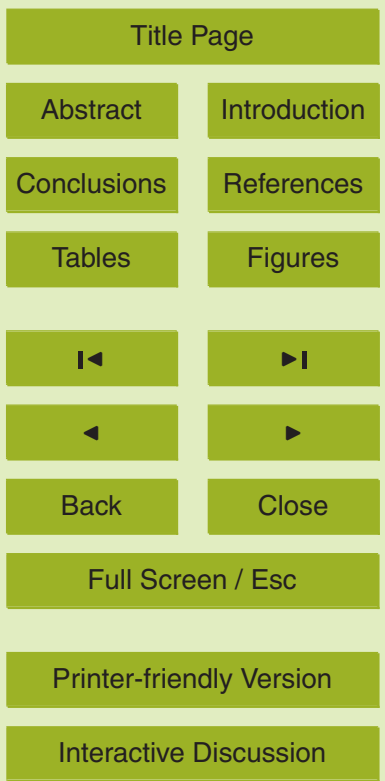


emission in the Eucalyptus sp. ecosystem in response to natural sunlight may have originated from living vegetation.

The calculated photo-induced gross release rate of $\mathrm{CO}$ from the sand in the field was one order of magnitude lower than that of the grass vegetation (Fig. 1). In contrast to 5 that of grass, the gross release rate of $\mathrm{CO}$ from sand in the field does not match that of isolated samples (few $\mathrm{mm}$ in depth) sand (Figs. 1 and 2). It is uncertain whether this discrepancy is caused by a much higher $\mathrm{CO}$ diffusion coefficient of the top of the sand in the field tests compared to that of the soil in the grass field. Regardless, a photoinduced positive gross release rate of $\mathrm{CO}$ from any type of soil surface has never been 10 reported earlier.

\subsubsection{Effects of UV}

The effect of natural UV irradiance on gross $\mathrm{CO}$ emission rates were tested at field conditions by shielding the measurement chamber with an almost completely UV-opaque chamber with little effect on total PAR transmission (Fig. 1). In response to this, the gross $\mathrm{CO}$ emission rates were about halved for both the grass field and the $100 \%$ sand. A study by Tarr et al. (1995) on the effect of artificial light on CO production by leaf litter indicated that UV-irradiation was a stronger catalyst than visible light. A similar response has been reported for photo-induced carbon dioxide production in terrestrial plant litter (Brand et al., 2009).

20 Thus, in addition to the global estimates of photo-induced $\mathrm{CO}$ emission by living vegetation due to visible light (Seiler and Giehl, 1977; Seiler et al., 1978) amounting to 50-200 Tgyr $^{-1}$ (Tarr et al., 1995) future global budgets need to include CO emission caused by natural UV irradiance. Future ecosystem chamber measurements of CO exchange should be deployed using UV-transparent materials for chamber constructions.

Further, it can be speculated if the UV-effects on $\mathrm{CO}$ exchange reported here are indirectly caused by the known long-term effects of UV on microbial activity, via acclimation to altered levels of UV intensity (Johnson et al., 2003). However, as the effects reported here are instant responses upon changes in UV intensity, this mechanism

BGD

9, 8449-8473, 2012

UV-induced carbon monoxide emission from sand and living vegetation

D. Bruhn et al.

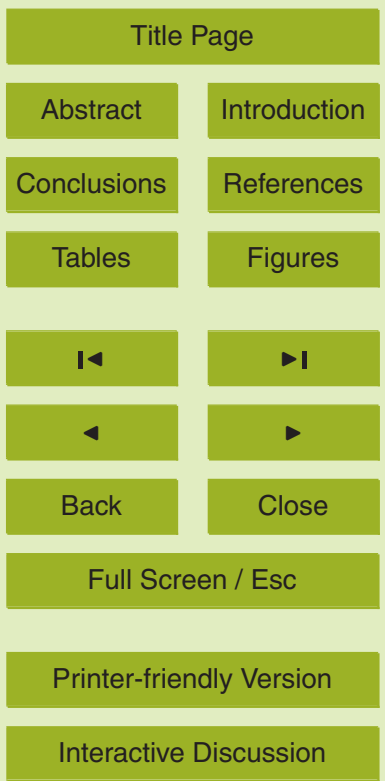


seems unlikely. Also, there was no net $\mathrm{CO}$ uptake measured in darkness for neither sand nor plants when tested uncoupled from the deep soil profile (i.e. in Walz chamber) (Fig. 5) and the temperature dependence of UV-induced CO emission is so low (Fig. 5) that it indicates an abiotic process, as discussed in Sect. 3.2.3. Thus, net up5 take of $\mathrm{CO}$ is only an issue when measurements a conducted at ecosystem scale, i.e. coupled to a deeper soil profile.

\subsection{Leaf and sand-atmosphere $\mathrm{CO}$ exchange}

\subsubsection{Natural sunlight}

Freshly excised green leaves of six different species exhibited rates of net (i.e. sub10 tracted rates in dark) CO release ranging from 965 to $2396 \mathrm{nmolCO} \mathrm{h}^{-1} \mathrm{~m}^{-2}$ (mean $1740 \mathrm{nmol} \mathrm{CO}^{-1} \mathrm{~m}^{-2}$ ) when exposed to natural sunlight (Fig. 3). These rates are of the same magnitude as the gross rates (i.e. incl. dark rates) reported by Tarr et al. (1995) by green leaves, $1800 \mathrm{nmolCOh}^{-1} \mathrm{~m}^{-2}$ in response to simulated sunlight $\left(650 \mathrm{Wm}^{-2}\right.$ UV-B + UV-A + PAR), and those by Yonemura et al. (1999) by green leaves, 1300 to $151550 \mathrm{nmolCOh}^{-1} \mathrm{~m}^{-2}$ in response to $490 \mathrm{Wm}^{-2}$ PAR (without UV). In comparison, Seiler et al. (1978) reported a mean photo-induced CO production by living plants of $386 \mathrm{nmolh}^{-1} \mathrm{~m}^{-2}$ in response to $50 \mathrm{Wm}^{-2}$ PAR (without UV).

Photo-induced $\mathrm{CO}$ emission rates by leaf litter are typically 5 to 10 times that of living plants (Tarr et al., 1995; Schade et al., 1999; Yonemura et al., 1999).

\subsubsection{Effects of UV}

Rates of $\mathrm{CO}$ emission by green leaves and sand increased near-linearly with increasing intensity of UV-B and UV-A (Fig. 4). Such linear irradiance responses are reported earlier for Vicia faba and Platanus acerfolia (Seiler and Giehl, 1977), Oryza sativa (Yonemura et al., 1999), and Sequoiadendron gigantum (Derendorp et al., 2011).

\section{BGD}

9, 8449-8473, 2012

UV-induced carbon monoxide emission from sand and living vegetation

D. Bruhn et al.

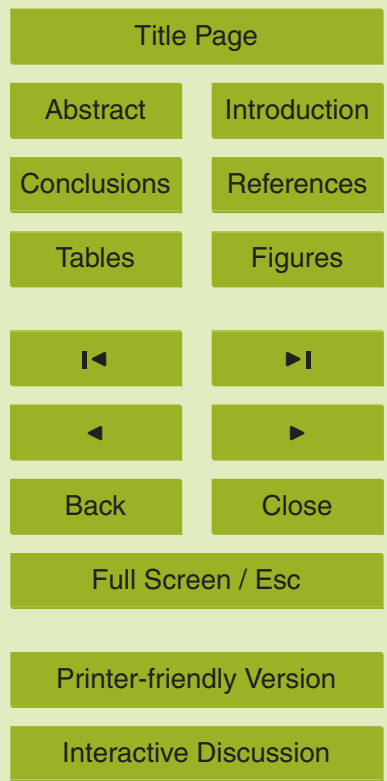


The lower the wavelength of the radiation, the higher was the measured $\mathrm{CO}$ rates at a given irradiance intensity, as illustrated by the difference in $\mathrm{CO}$ emissions under similar UV-A and UV-B intensities (Fig. 4). Similar results have been proven in leaf litter (Tarr et al., 1995; Schade et al., 1999).

5 The exact nature of the origin of the produced CO remains unclear, but UV-induced emission rates of $\mathrm{CO}$ from dead plant material are in several studies observed to be oxygen dependent (Tarr et al., 1995; Yonemura et al., 1999; Derendorp et al., 2011). In studies on green Lima Bean leaves Tarr et al. (1995) indicated that the photoproduction of $\mathrm{CO}$ occurred inside the leaves. This could however not be confirmed 10 by Yonemura et al. (1999). In the present study, the measured rates of UV-induced CO emission from sand were reduced to $57 \%$ upon heating at $650^{\circ} \mathrm{C}$ for $24 \mathrm{~h}$. This indicates that for the UV-induced $\mathrm{CO}$ emission by sand roughly half is caused by organic material. Further, UV-induced CO emission potential from sand, which was washed in $\mathrm{HCl}$ prior to heat treatment, was only ca. $3 \%$ of that by untreated sand (just washed in treatment) the UV-induced $\mathrm{CO}$ emission from sand was almost eliminated. This clearly indicates that the reported rates of $\mathrm{CO}$ emission are fully accounted for by a source at the surface of the tested material.

\subsubsection{Effects of temperature}

20 The effect of temperature $(T)$ on the $\mathrm{CO}$ emission rate, ER, can be described the exponential function $E R(T)=\alpha e^{\beta T}$ (Fig. 5). Under UV-B, the mean temperature response of the UV-induced ( $E R_{U V}$ subtracted $\left.E R_{\text {dark }}\right) C O$ emission of the two plant species resulted in $\alpha=9410 \mathrm{nmolCOh}^{-1} \mathrm{~m}^{-2}$ and a temperature sensitivity, $\beta=0.017$; for sand, $\alpha=6651 \mathrm{nmolCOh}^{-1} \mathrm{~m}^{-2}$ and $\beta=0.013$. In darkness, the mean temperature re25 sponse of the emission of the two plant species resulted in $\alpha=11 \mathrm{nmolCO} \mathrm{h}^{-1} \mathrm{~m}^{-2}$ and a temperature sensitivity, $\beta=0.104$; for sand, $\alpha=28 \mathrm{nmolCOh}^{-1} \mathrm{~m}^{-2}$ and $\beta=0.025$. Thus, the temperature sensitivity under UV-B is similar between green leaves and sand and so low that it indicates an abiotic process (Derendorp et al., 2011). In darkness, 8459
BGD

9, 8449-8473, 2012

UV-induced carbon monoxide emission from sand and living vegetation

D. Bruhn et al.

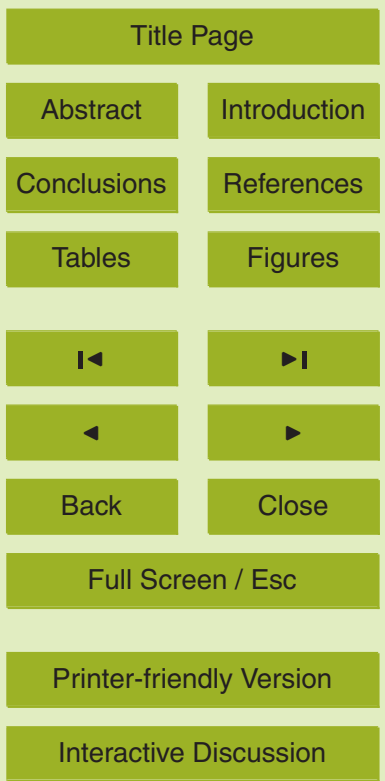


however, the temperature sensitivity for the green leaves was not unlike the activation energy associated with biological processes.

\subsection{Global estimates}

It is possible that the otherwise natural breakdown of trace gasses by UV-radiation with 5 the presence of radicals is partially or completely unnoticed in a laboratory scale setup, when the rate of carrier gas is fast enough. It is important to recall that $\mathrm{CO}$ depletion by radicals is "simply" an important CO-sink. This sink is, however, already a known sink and thus already accounted for (IPCC, 2001). If such mechanism is in operation, which cannot be concluded from the current study, the observed CO release rates should be considered gross rates. Nevertheless, the measured UV-induced gross rate of CO emission is still very relevant and important to extrapolate. This is because net CO release is a combination of $\mathrm{CO}$ release and $\mathrm{CO}$ uptake. Indeed, all gross rates of $\mathrm{CO}$ uptake and $\mathrm{CO}$ release are necessary to extrapolate in order to fully close the global CO budget.

A global estimate of the terrestrial $\mathrm{CO}$ source strength would be the sum of the ER of both soil and vegetation. Previous studies have either not examined dark $\mathrm{CO}$ emission potential of vegetation (living leaves or litter) or only found insignificant or very low ER (Seiler and Giehl, 1977; Seiler et al., 1978; Tarr et al., 1995; Yonemura et al., 1999; Derendorp et al., 2011). The results presented in Fig. 5 confirm this for both

20 leaves and sand. Indeed, the global estimate of the chemical oxidation, independent of photo-regulation, of decaying soil organic matter (SOM) does not amount to more than 9.4 $\mathrm{Tgyr}^{-1}$ (Potter et al., 1996).

The ER by plant litter has been estimated to contribute with $50-170 \mathrm{Tgyr}^{-1}$ globally (Tarr et al., 1995; Schade and Crutzen, 1999). This estimate includes the effect of both 25 the UV- and the PAR-component of sunlight (Tarr et al., 1995; Schade and Crutzen, 1999). However, in the studies underlying the photo-induced $\mathrm{CO}$ emission by living plants, which was incorporated in previous IPCC $(1995,2001)$ global CO budgets, the UV-component of (sun)-light was not considered (Seiler and Giehl, 1977; Seiler

\section{BGD}

9, 8449-8473, 2012

UV-induced carbon monoxide emission from sand and living vegetation

D. Bruhn et al.

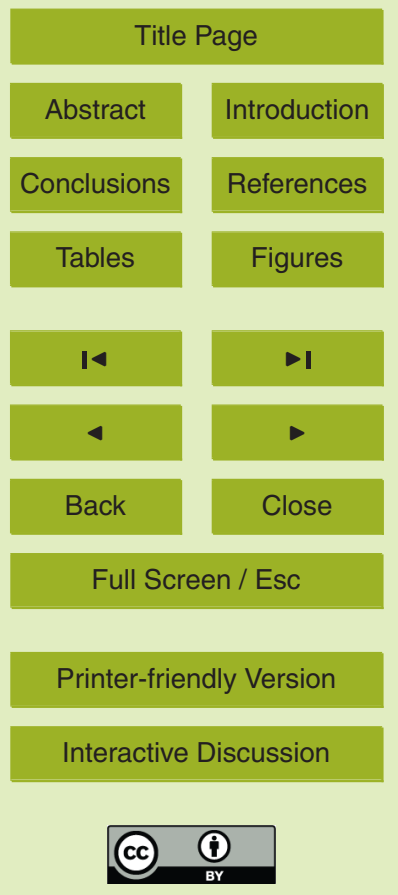


et al., 1978). Thus, we focus to estimate the global contribution of $\mathrm{CO}$ emission by living vegetation and sand induced by natural solar UV radiation and its dependency on temperature. From Figs. 1 and 2 it is clear that the UV-component of natural sunlight is very important in determining the gross rate of $\mathrm{CO}$ emission in a grass ecosystem, 5 both for vegetation and sand.

\subsubsection{Living vegetation}

Daytime ER by living vegetation is the sum of ER independent of photo-regulation in relation to temperature [ER $\left.\mathrm{E}_{\text {veg,dark }}(T)\right]$, ER induced by UV-radiation in relation to temperature $\left[E R_{\text {veg,Uv }}(T)\right]$, and ER induced by visible light (PAR) in relation to temperature $10 \quad\left[\operatorname{ER}_{\text {veg,PAR }}(T)\right]:$

$\mathrm{ER}_{\text {veg, daytime }}=\mathrm{ER}_{\text {veg,dark }}(T)+\mathrm{ER}_{\mathrm{veg}, \mathrm{UV}}(T)+\mathrm{ER}_{\mathrm{veg}, \mathrm{PAR}}(T)$

Based on the results in Fig. 5, we decided to ignore $\mathrm{ER}_{\text {veg,dark }}(T)$ and $\mathrm{ER}_{\text {veg,PAR }}(T)$ was already incorporated in previous IPCC $(1995,2001)$ global CO budgets. To estimate $\mathrm{ER}_{\text {veg,UV }}(T)$ at ecosystem level we assume that the temperature sensitivity, $e^{\beta T}$ (where ${ }_{15} \beta=0.017$ based on the mean of F. elastic and B. oleracea, Fig. 5) applies to living leaves of all species. Further, in order to apply this temperature sensitivity globally, the

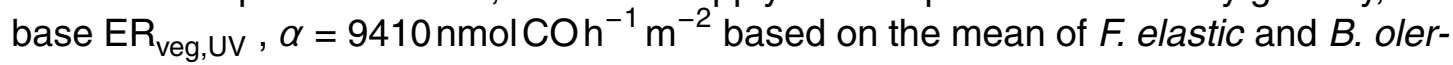
acea, Fig. 5) needs to be scaled to a mean base $\mathrm{ER}_{\mathrm{veg}, \mathrm{Uv}}$ of all six tested species, $\alpha^{\prime}=$

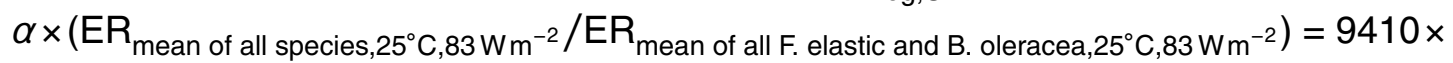
$20 \quad(23057 / 18614)=11656$.

In Fig. 4 is demonstrated a near-linear relationship between irradiance of both UV-B and UV-A and CO emissions. Therefore, the $\alpha^{\prime}$ estimated at $83 \mathrm{Wm}^{-2} \mathrm{UV}-\mathrm{B}$ can be scaled to $\alpha^{\prime \prime}$, a base ER $\mathrm{E}_{\text {veg,Uv }}$ induced by total natural solar UV (Fig. 3); $\alpha^{\prime \prime}=\alpha^{\prime} \times$ $\left(E_{\text {veg,sun }, 25^{\circ} \mathrm{C}} / \mathrm{ER}_{\text {mean of all species, } 83 \mathrm{Wm}^{-2}, 25^{\circ} \mathrm{C}}\right)$, where $\mathrm{ER}_{\text {veg,sun }, 25^{\circ} \mathrm{C}}$ only represents $\mathrm{ER}$ in full sun subtracted ER in sun excluding UV (Fig. 2). The potential error with this linear down-scaling of $\mathrm{ER}_{\text {mean of all species, } 83 \mathrm{Wm}^{-2}-2,25^{\circ} \mathrm{C}}$ to that in natural solar $\mathrm{UV}$ is a minor 8461

\section{BGD}

9, 8449-8473, 2012

UV-induced carbon monoxide emission

from sand and living vegetation

D. Bruhn et al.

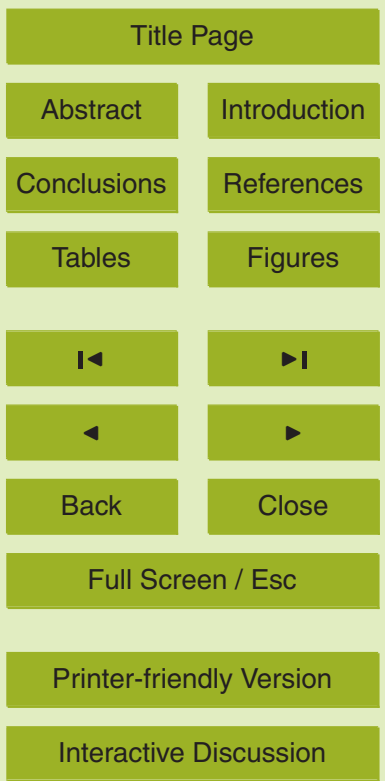


underestimation of ER because the relationship between irradiance of UV-B and CO emissions is not perfectly linear (Fig. 3). The highest levels of $U V_{310 \mathrm{~nm}}$ applied for the scaling is $150 \mathrm{mWm}^{-2}$.

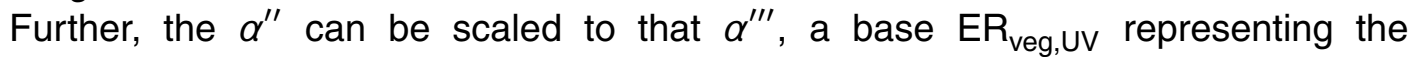
5 UV-induced ER by the uncut vegetation at ecosystem level (Fig. 1); $\alpha^{\prime \prime \prime}=\alpha^{\prime \prime} \times$ $\left(E R_{\text {eco,sun, } 21.4^{\circ} \mathrm{C}} / E_{\text {cut veg,sun, } 21.4^{\circ} \mathrm{C}}\right)$. The $\mathrm{ER}_{\text {eco,sun, } 21.4^{\circ} \mathrm{C}}$ was measured at ca. $50 \mathrm{~mW}$ UV-B (natural sunlight), why the UV-effect can be scaled by the measured $U V_{310 \mathrm{~nm}}$ though time and space. Thus, the UV-induced CO ER by living vegetation can be estimated as

$$
\mathrm{ER}_{\text {veg,Uv }}(T)=\alpha^{\prime \prime \prime} \times e^{\beta T} \times \mathrm{UV}_{310 \mathrm{~nm}} / 50=18.0 \mathrm{nmolCOh}^{-1} \mathrm{~m}^{-2} \times e^{0.017 T} \times \mathrm{UV}_{310 \mathrm{~nm}}
$$

The temporal variation in estimated global $\mathrm{ER}_{\mathrm{veg}, \mathrm{UV}}(T)$ is presented in Table 1 and the geographical variation is presented in Fig. 6.

\subsubsection{Sand}

Here we provide a conservative estimate of the UV-induced ER by soil surfaces, which 15 is based on current observations using sand that has a relatively low SOM content. Similar to vegetation, daytime ER by sand can be estimated as

$\mathrm{ER}_{\text {sand,daytime }}=\mathrm{ER}_{\text {sand,dark }}(T)+\mathrm{ER}_{\text {sand, } \mathrm{UV}}(T)+\mathrm{ER}_{\text {sand,PAR }}(T)$

Also for sand, we ignore $\mathrm{ER}_{\text {sand,dark }}(T)$ based on the negligible rates shown in Fig. 5. We have not measured $\mathrm{ER}_{\text {sand,PAR }}(T)$ and do therefore not provide a global estimate.

20 However, ER $\mathrm{E}_{\text {sand,UV }}(T)$ can be estimated using the temperature sensitivity $e^{\beta T}$ (where $\beta=0.013$ ) from Fig. 5 , which is assumed to apply to all sand. Because ER $_{\text {sand,UV }}$ was reduced to $56 \%$ upon heating at $650{ }^{\circ} \mathrm{C}$ for $24 \mathrm{~h}$, it is likely that roughly half $\mathrm{ER}_{\text {sand,Uv }}$ is derived from organic material. Therefore, it is possible to provide an

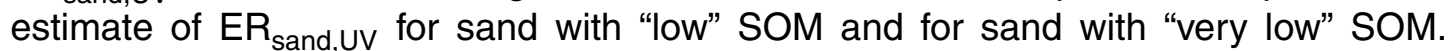
25 The latter, and more conservative estimate, is given by scaling the base ER $\mathrm{R}_{\text {sand,UV }}$, 8462

\section{BGD}

9, 8449-8473, 2012

UV-induced carbon monoxide emission from sand and living vegetation

D. Bruhn et al.

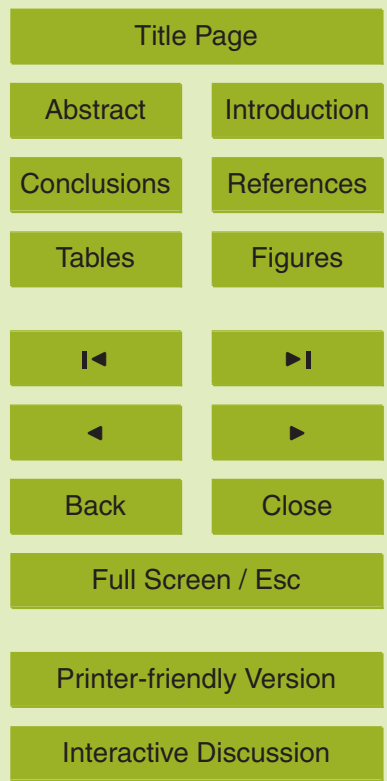


$\alpha=6651 \mathrm{nmolCOh}^{-1} \mathrm{~m}^{-2}$, with 0.57 . As for vegetation, the $\alpha$ estimated at $83 \mathrm{Wm}^{-2}$ UV-B is scaled to $\alpha^{\prime}$, a base $\mathrm{ER}_{\text {sand,UV }}$ induced by total natural solar UV (Fig. 3); BGD $\alpha^{\prime \prime}=\alpha^{\prime} \times\left(\mathrm{ER}_{\text {sand, sun }, 25^{\circ} \mathrm{C}} / \mathrm{ER}_{\text {sand }, 83 \mathrm{Wm}^{-2}, 25^{\circ} \mathrm{C}}\right)$, where $\mathrm{ER}_{\text {sand,sun, } 25^{\circ} \mathrm{C}}$ only represents $\mathrm{ER}$ in full sun subtracted ER in sun excluding UV (Fig. 2).

$5 \quad$ Thus the UV-induced CO ER by sand with "very low" SOM can be estimated as

$\mathrm{ER}_{\text {sand, UV }}(T)=\alpha^{\prime \prime} \times e^{\beta T} \times \mathrm{UV}_{310 \mathrm{~nm}} / 50=4.0 \mathrm{nmolCOh}^{-1} \mathrm{~m}^{-2} \times e^{0.013 T} \times \mathrm{UV}_{310 \mathrm{~nm}}$

and, the UV-induced CO ER by sand with "low" SOM can be estimated as

$\mathrm{ER}_{\text {sand, UV }}(T)=\alpha^{\prime \prime} \times e^{\beta T} \times \mathrm{UV}_{310 \mathrm{~nm}} / 50=7.2 \mathrm{nmolCOh}^{-1} \mathrm{~m}^{-2} \times e^{0.013 T} \times \mathrm{UV}_{310 \mathrm{~nm}}$

The temporal variation in estimated global $\mathrm{ER}_{\mathrm{veg}, \mathrm{UV}}(T)$ is presented in Table 1 and 10 the geographical variation is presented in Fig. 6. When scaled to global levels, the UVinduced emission of $\mathrm{CO}$ by the major types of terrestrial surfaces, living leaves and soil (here represented by sand), amounts up to $28 \mathrm{Tgyr}^{-1}$. This source has till now not been accounted for by IPCC. In addition to this estimate are other known sources that ought to be considered. These are (i) photo-chemically induced emission rates of CO 15 by dead plant materiel (litter), estimated to contribute with $50-170 \mathrm{Tgyr}^{-1}$ globally (Tarr et al., 1995; Schade and Crutzen, 1999), and (ii) a chemical oxidation, independent of photo-regulation, of decaying SOM, estimated to contribute with 9.4 $\mathrm{Tgyr}^{-1}$ (Potter et al., 1996). The hitherto unaccounted terrestrial sources of $\mathrm{CO}$ up to $207 \mathrm{Tg} \mathrm{yr}^{-1}$ in global CO budgets are more than those already accounted for, 50-200 $\mathrm{Tgyr}^{-1}$, and

20 importantly almost two-thirds of the latest estimated global burden of $360 \mathrm{Tg} \mathrm{CO} \mathrm{yr}^{-1}$ (IPCC, 2001).

UV-induced carbon monoxide emission from sand and living vegetation

D. Bruhn et al.

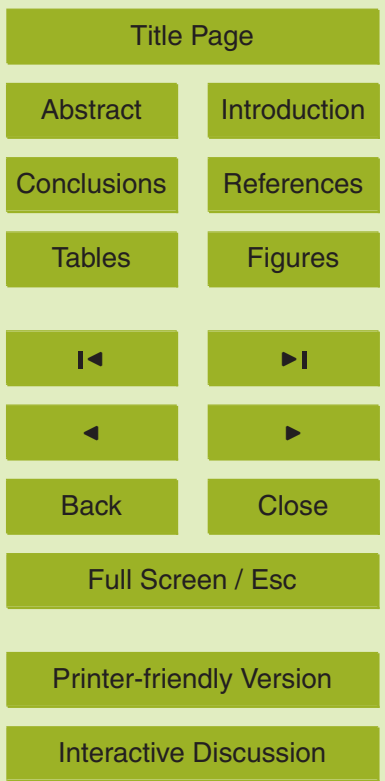




\section{Conclusions}

We examined UV-induced emissions of carbon monoxide (CO) from specific surfaces abundant in terrestrial ecosystems, i.e. vegetation and mineral particles (sand), and from whole-chamber soil-vegetation studies. All examined plant species as well as 5 sand particles exhibited emission of $\mathrm{CO}$ in response to both artificial UV-radiation and the UV-component of natural solar radiation. The UV-induced rate of $\mathrm{CO}$ emission exhibited a rather low dependence on temperature, indicating an abiotic process. The emission of $\mathrm{CO}$ in response to the UV-component of natural solar radiation was also evident at the ecosystem scale. When scaled to the global level, the UV-induced emission of $\mathrm{CO}$ by the major types of terrestrial surfaces, living leaves and soil (here represented by sand), amounts up to $28 \mathrm{Tg} \mathrm{yr}^{-1}$.

\section{References}

Brand, L. A., Bohnet, C., and King, J. Y.: Photochemically induced carbon dioxide production as a mechanism for carbon loss from plant litter in arid ecosystems, J. Geophys. Res., 114,

Bruhn, D., Mikkelsen, T. N., Øbro, J., Willats, W. G. T., and Ambus, P.: Effects of temperature, ultraviolet radiation and pectin methyl esterase on aerobic methane release from plant material, Plant Biol., 11, 43-48, 2009

Cen, Y. P. and Bornman, J. F.: The effect of exposure to enhanced UV-B radiation on the penetration of monochromatic and polychromatic UV-B radiation in leaves of Brassica-napus, Physiol. Plant., 87, 249-255, 1993.

Derendorp, L., Quist, J. B., Holzinger, R., and Röckmann, T.: Emissisions of $\mathrm{H}_{2}$ and $\mathrm{CO}$ from leaf litter of Sequoiadendron giganteum and their dependence on UV radiation and temperature, Atmos. Environ., 45, 7520-7524, 2011.

25 Galbally, I., Meyer, C. P., Wang, Y.-P., and Kirstine, W.: Soil-atmosphere exchange of $\mathrm{CH}_{4}$, CO, $\mathrm{N}_{2} \mathrm{O}$ and $\mathrm{NO}_{x}$ nd the effects of land-use change in the semiarid Mallee system in Southeastern Australia, Global Change Biol., 16, 2407-2419, 2010.
BGD

9, 8449-8473, 2012

UV-induced carbon monoxide emission from sand and living vegetation

D. Bruhn et al.

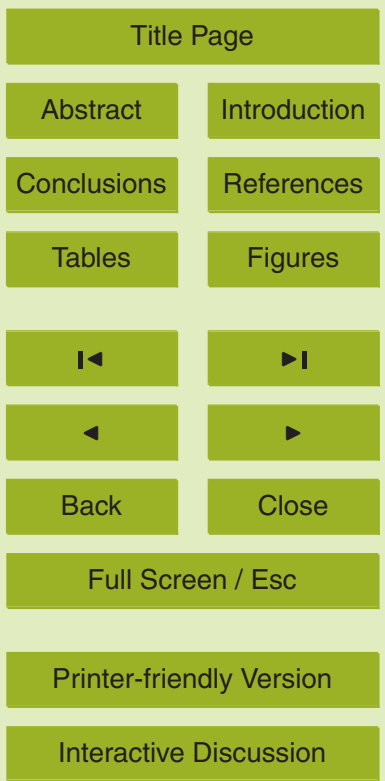


Guenther, A.: The contribution of reactive carbon emissions from vegetation to the carbon balance of terrestrial ecosystems, Chemosphere, 49, 837-844, 2002.

IPCC: Radiative forcing of climate change, Climate Change 1995, The Science of Climate Change, Contribution of WGI to the Second Assessment Report of the Intergovernmental 5 Panel on Climate Change, Chapt. 2, edited by: Schimel, D., Alves, D., Enting, I., Heimann, M., Joos, R., Raynaud, D., Wigley, T., Prather, M., Derwent, R., Ehhalt, D., Eraser, R., Sanhueza, E., Zhou, X., Jonas, R., Charlson, R., Rodhe, H., Sadasivan, S., Shine, K. R., Fouquart, Y., Ramaswamy, V., Solomon, S., Srinivasan, J., Albritton, D., Derwent, Isaksen, L., Lal, M., and Wuebbles, D., Cambridge University Press, Cambridge, UK and New York, NY, USA, 51-64, 1995.

IPCC: Climate Change 2001: The Scientific Basis. Contribution of Working Group I to the Third Assessment Report of the Intergovernmental Panel on Climate Change, edited by: Houghton, J. T., Ding, Y., Griggs, D. J., Noguer, M., van der Linden, P. J., Dai, X., Maskell, K., and Johnson, C. A., Cambridge University Press, Cambridge, UK and New York, NY, USA, 15881 pp., 2001.

Jacobs, J. F., Koper, G. J. M., and Ursem, W. N. J.: UV protective coatings: a botanical approach, Prog. Org. Coat., 58, 166-171, 2007.

Johnson, D., Campbell, C. D., Lee, J. A., Callaghan, T. V., and Gwun-Jones, D.: Arctic microorganisms respond more to elevated UV-B radiation than $\mathrm{CO}_{2}$, Nature, 416, 82-83, 2003.

20 Khalil, M. A. K. and Rasmussen, R. A.: The global carbon monoxide: trends and mass balance, Chemosphere, 20, 227-242, 1990.

King, G. M. and Weber, C. F.: Distribution, diversity and ecology of aerobic CO-oxidizing bacteria, Nat. Rev. Microbiol., 5, 107-118, 2007.

Liakoura, V., Bornmann, J. F., and Karabourniotis, G.: The ability of abaxial and adaxial epidermis of sun and shade leaves to attenuate UV-A and UV-B radiation in relation to the UV absorbing capacity of the whole leaf methanolic extracts, Physiol. Plant., 117, 33-43, 2003.

Potter, C. S., Klooster, S. A., and Chatfield, R. B.: Consumption and production of carbon monoxide in soils: a global model analysis of spatial and seasonal variation, Chemosphere, 33, 1175-1193, 1996.

so Schade, G. W. and Crutzen, P. J.: CO emissions from degrading plant matter (II). Estimate of a global source strength, Tellus, 51B, 909-918, 1999.

Schade, G. W., Hofmann, R.-F., and Crutzen, P. J.: CO emissions from degrading plant matter (I). Measurements, Tellus, 51B, 889-908, 1999.

\section{UV-induced carbon monoxide emission \\ from sand and living vegetation}

D. Bruhn et al.

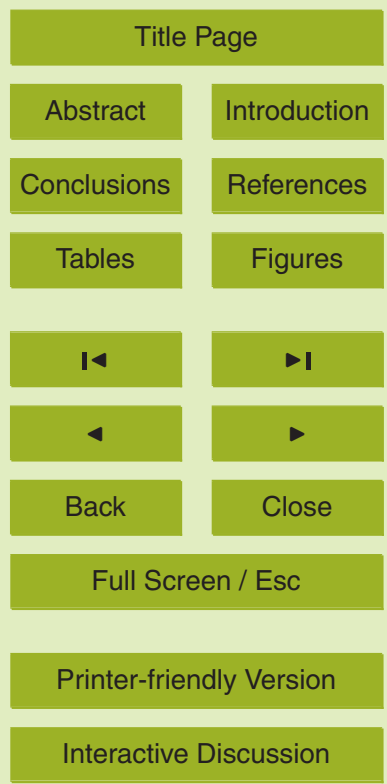


Seiler, W. and Giehl, H.: Influence of plants on the atmospheric carbon monoxide, Geophys. Res. Lett., 8, 329-332, 1977.

Seiler, W., Giehl, H., and Bunse, G.: The influence of plants on atmospheric carbon monoxide and dinitrogen oxide, Pure Appl. Geophys., 116, 439-451, 1978.

5 Tarr, M. A., Miller, W. L., and Zapp, R. G.: Direct carbon monoxide photoproduction from plant matter, J. Geophys. Res., 100, 11403-11413, 1995.

Yonemura, S., Morokuma, M., Kawashima, S., and Tsuruta, H.: Carbon monoxide photoproduction from rice and maize leaves, Atmos. Environ., 33, 2915-2920, 1999.

BGD

9, 8449-8473, 2012

\section{UV-induced carbon monoxide emission from sand and living vegetation}

D. Bruhn et al.

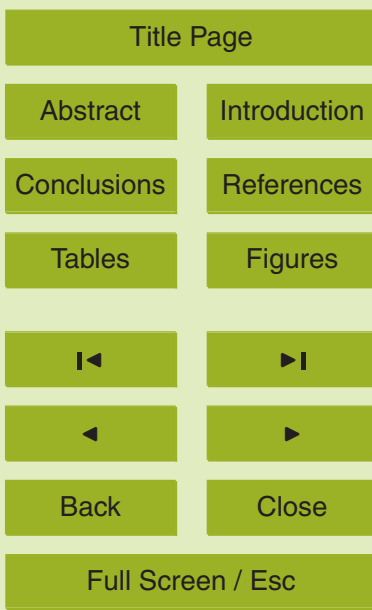

Printer-friendly Version

Interactive Discussion 
BGD

9, 8449-8473, 2012

UV-induced carbon monoxide emission from sand and living vegetation

\begin{tabular}{lcllcc}
\hline Month & ER $_{\text {veg }}$ & ER $_{\text {sand-very low Som }}$ & ER $_{\text {sand-low SOM }}$ & $\begin{array}{l}\mathrm{ER}_{\text {veg }}+ \\
\mathrm{ER}_{\text {sand-very lowsom }}\end{array}$ & $\begin{array}{l}\mathrm{ER}_{\text {veg }}+ \\
\text { ER }_{\text {sand-low SOM }}\end{array}$ \\
\hline Jan & 1.57 & 0.22 & 0.40 & 1.79 & 1.96 \\
Feb & 1.52 & 0.22 & 0.40 & 1.75 & 1.93 \\
Mar & 1.68 & 0.29 & 0.52 & 1.97 & 2.20 \\
Apr & 1.71 & 0.33 & 0.59 & 2.03 & 2.30 \\
May & 1.98 & 0.36 & 0.64 & 2.33 & 2.62 \\
Jun & 2.23 & 0.36 & 0.65 & 2.59 & 2.88 \\
Jul & 2.41 & 0.36 & 0.65 & 2.77 & 3.06 \\
Aug & 2.23 & 0.35 & 0.62 & 2.58 & 2.86 \\
Sep & 1.92 & 0.32 & 0.57 & 2.24 & 2.49 \\
Oct & 1.72 & 0.29 & 0.52 & 2.01 & 2.24 \\
Nov & 1.52 & 0.24 & 0.42 & 1.75 & 1.94 \\
Dec & 1.52 & 0.22 & 0.40 & 1.74 & 1.92 \\
Total & 22.00 & 3.56 & 6.40 & 25.55 & 28.39 \\
\hline
\end{tabular}

D. Bruhn et al.

Title Page

Abstract

Introduction

Conclusions

References

Tables

Figures

14

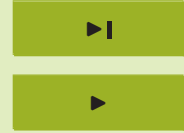

Back

Close

Full Screen / Esc

Printer-friendly Version

Interactive Discussion 

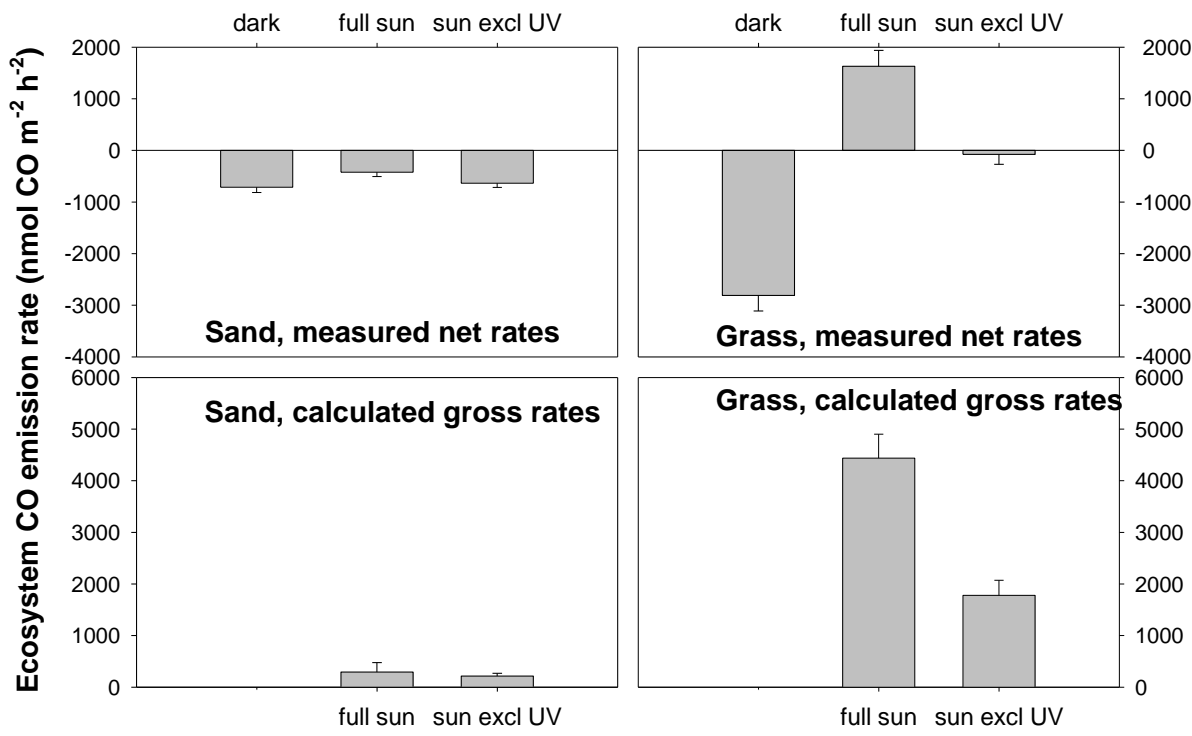

Light treatment

Fig. 1. Ecosystem $\mathrm{CO}$ net- and gross emission rates in dark. sunlight and UV-excluded sunlight. Measurements were conducted with a Plexiglas chamber at ambient temperature (grass ecosystem $\left[T=21.38^{\circ} \mathrm{C} ; n=22\right]$; sand $\left.\left[T=13.03^{\circ} \mathrm{C} ; n=7\right]\right)$. Values shown are means \pm s.e. The order of treatments (dark. full sun. and sun screened for UV) was alternated between replicates. For the Plexiglas ecosystem and sand measurements the mean ( \pm s.e.) level of UV-B $(280-315 \mathrm{~nm})$ was $0.50 \pm 0.01 \mathrm{Wm}^{-2}$ and the mean ( \pm s.e.) PAR was $711 \pm$ s.e. $16 \mu$ mol photons $\mathrm{m}^{-2} \mathrm{~s}^{-1}$.
BGD

9, 8449-8473, 2012

UV-induced carbon monoxide emission from sand and living vegetation

D. Bruhn et al.

\section{Title Page}

\section{Abstract}

Introduction

Conclusions

References

Tables

Figures

14

4

Back

Close

\section{Full Screen / Esc}

Printer-friendly Version

Interactive Discussion 


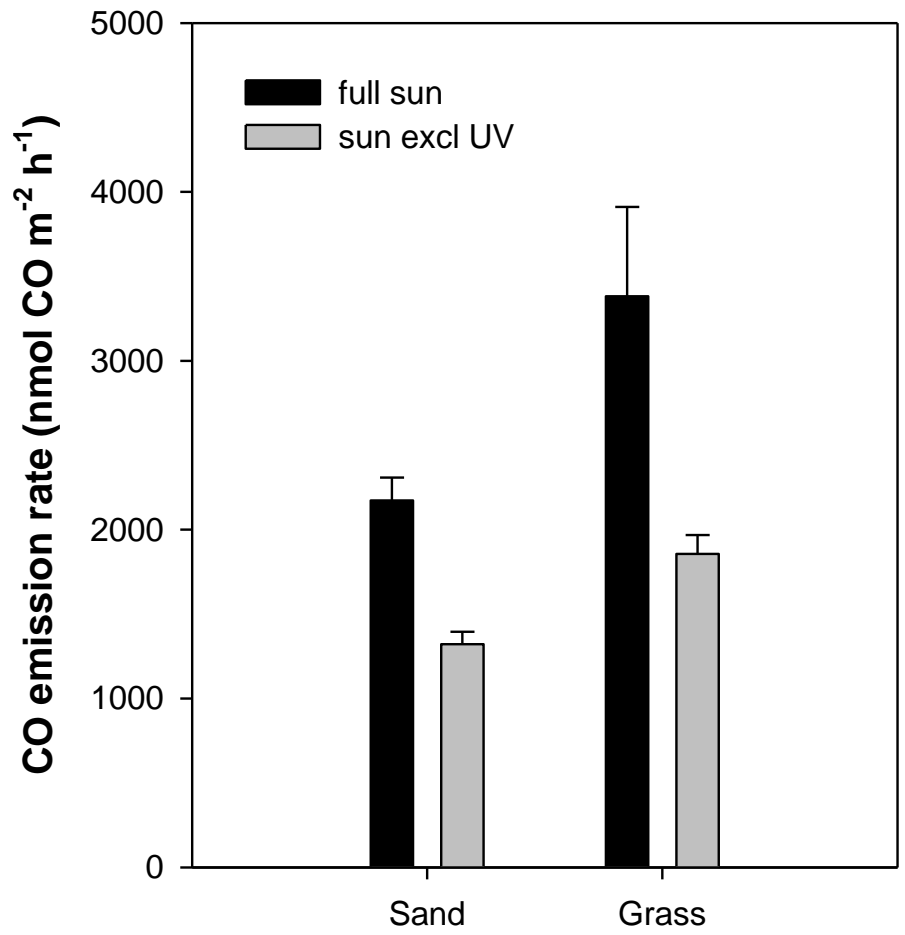

Fig. 2. Leaf- and low SOM sand $C O$ emission rates (mean \pm s.e.). Measurements were conducted with a temperature controlled chamber at $25^{\circ} \mathrm{C}$ (cut vegetation $[n=4]$ from the grass ecosystem; sample of low SOM sandsand $[n=4])$. Values shown are means \pm s.e. The order of treatments (full sun and sun screened for UV) was alternated between replicates. For the temperature controlled chamber measurements the mean ( \pm s.e.) level of UV-B $(280-315 \mathrm{~nm})$ was $0.51 \pm 0.03 \mathrm{Wm}^{-2}$ and the mean ( \pm s.e.) PAR was $789 \pm$ s.e. $47 \mu \mathrm{mol}$ photons $\mathrm{m}^{-2} \mathrm{~s}^{-1}$.
BGD

9, 8449-8473, 2012

UV-induced carbon monoxide emission from sand and living vegetation

D. Bruhn et al.

\section{Title Page}

\section{Abstract}

Conclusions

Tables

14

4

Back
Introduction

References

Figures

$\rightarrow 1$

$>$

Close

\section{Full Screen / Esc}

Printer-friendly Version

Interactive Discussion 


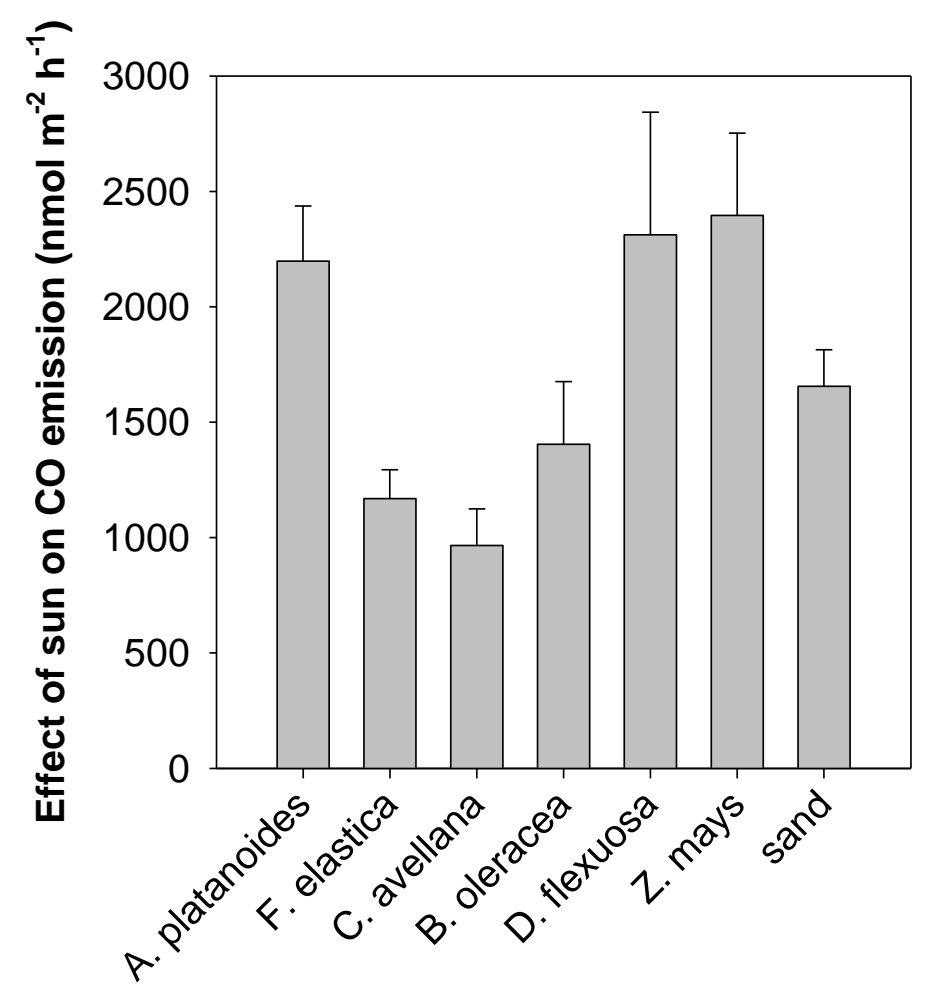

Fig. 3. The effect of solar radiation on the CO emission rates (ER) by leaves and low SOM sand (mean \pm s.e. of $E R_{\text {light }}-E R_{\text {dark }}$ ). Measurements were conducted with a temperature controlled chamber at $25^{\circ} \mathrm{C}$ The order of treatments (full sun and dark) was alternated between replicates. For the temperature controlled chamber measurements the mean $( \pm$ s.e.) level of UV-B $(280-315 \mathrm{~nm})$ was $0.51 \pm 0.03 \mathrm{Wm}^{-2}$ and the mean $( \pm$ s.e.) PAR was $789 \pm$ s.e. $47 \mu$ mol photons $\mathrm{m}^{-2} \mathrm{~s}^{-1}$.
BGD

9, 8449-8473, 2012

UV-induced carbon monoxide emission from sand and living vegetation

D. Bruhn et al.

\section{Title Page}

\section{Abstract}

Conclusions

Tables

14

Back
Introduction

References

Figures

$\rightarrow$

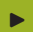

Close

\section{Full Screen / Esc}

Printer-friendly Version

Interactive Discussion 


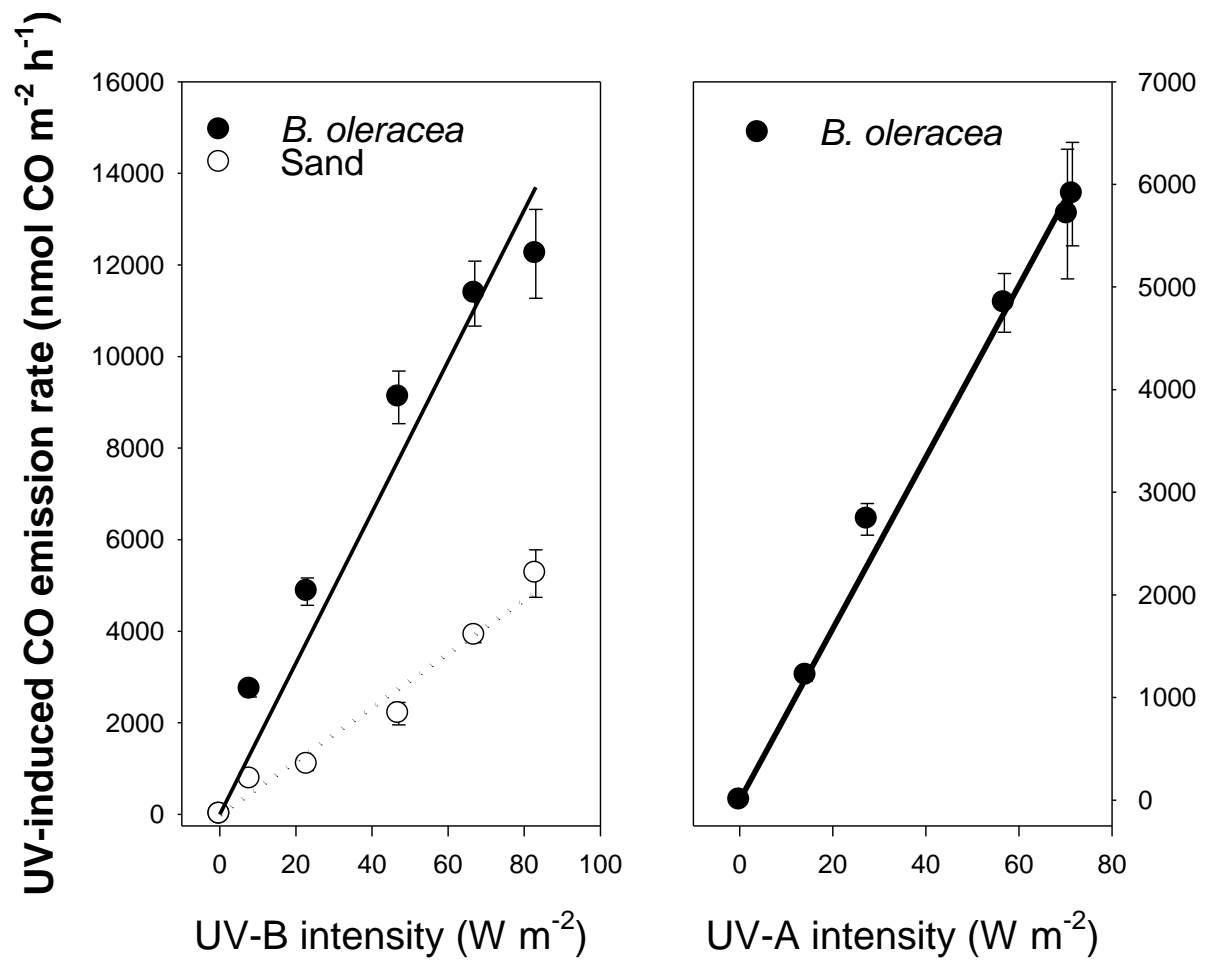

Fig. 4. The irradiance response of $\mathrm{CO}$ emission rate (ER) by leaf and low SOM sand (mean \pm s.e. of $\mathrm{ER}_{\text {light }}-\mathrm{ER}_{\text {dark }}$ ) at $25^{\circ} \mathrm{C}$.

\section{BGD}

9, 8449-8473, 2012

\section{UV-induced carbon monoxide emission from sand and living vegetation \\ D. Bruhn et al.}

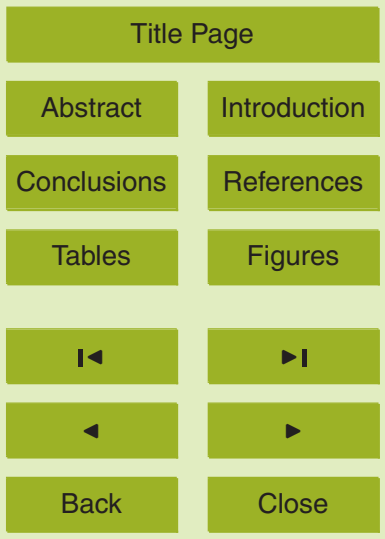

Full Screen / Esc

Printer-friendly Version

Interactive Discussion 


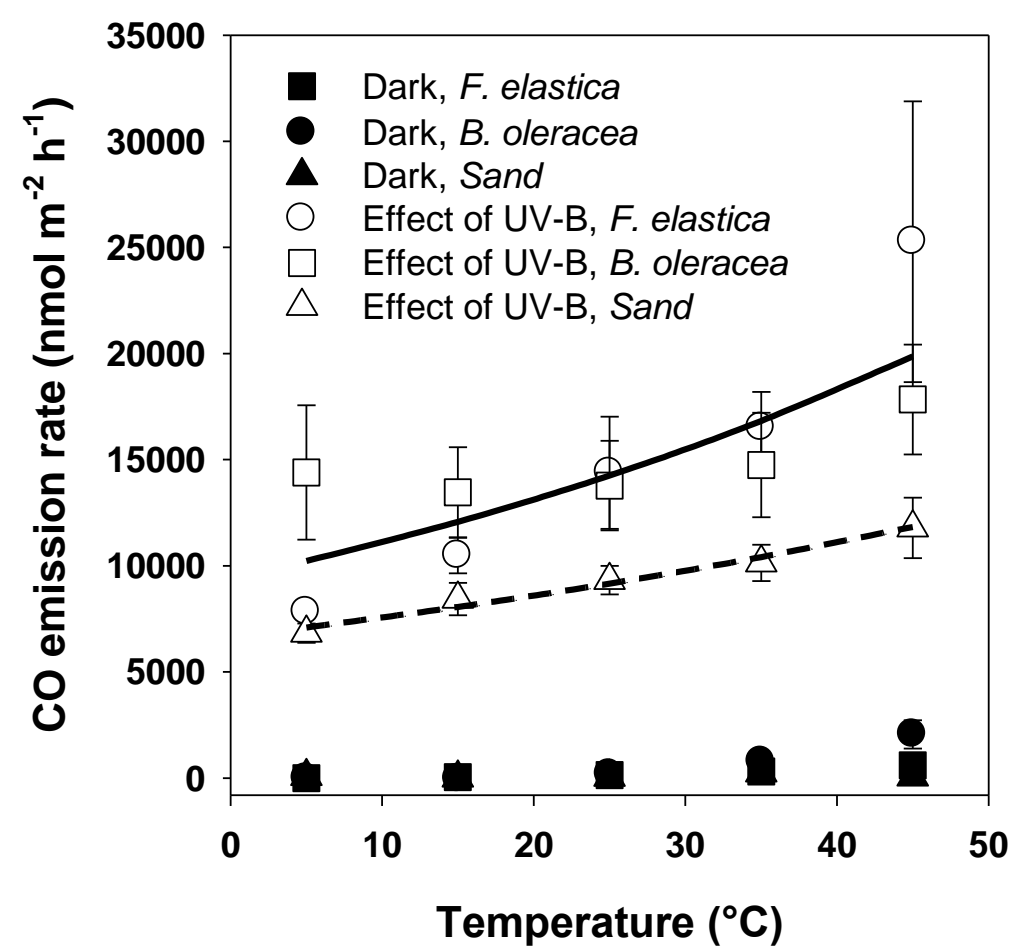

Fig. 5. Temperature dependence of UV-induced $\mathrm{CO}$ emission rate (ER) by leaf and low SOM sand $\left(E R_{\text {light }}-E R_{\text {dark }}\right)$ and dark $C O$ emission rate $(m e a n \pm s . e$.$) . The full line represents an$ exponential regression to data for leaves and the dashed line represents and exponential regression to data for sand. See Sect. 3.2.3. for equation coefficients.

\section{BGD}

9, 8449-8473, 2012

UV-induced carbon monoxide emission from sand and living vegetation

D. Bruhn et al.

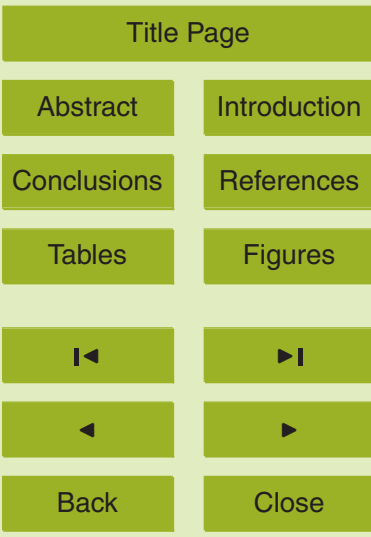

Full Screen / Esc

Printer-friendly Version 


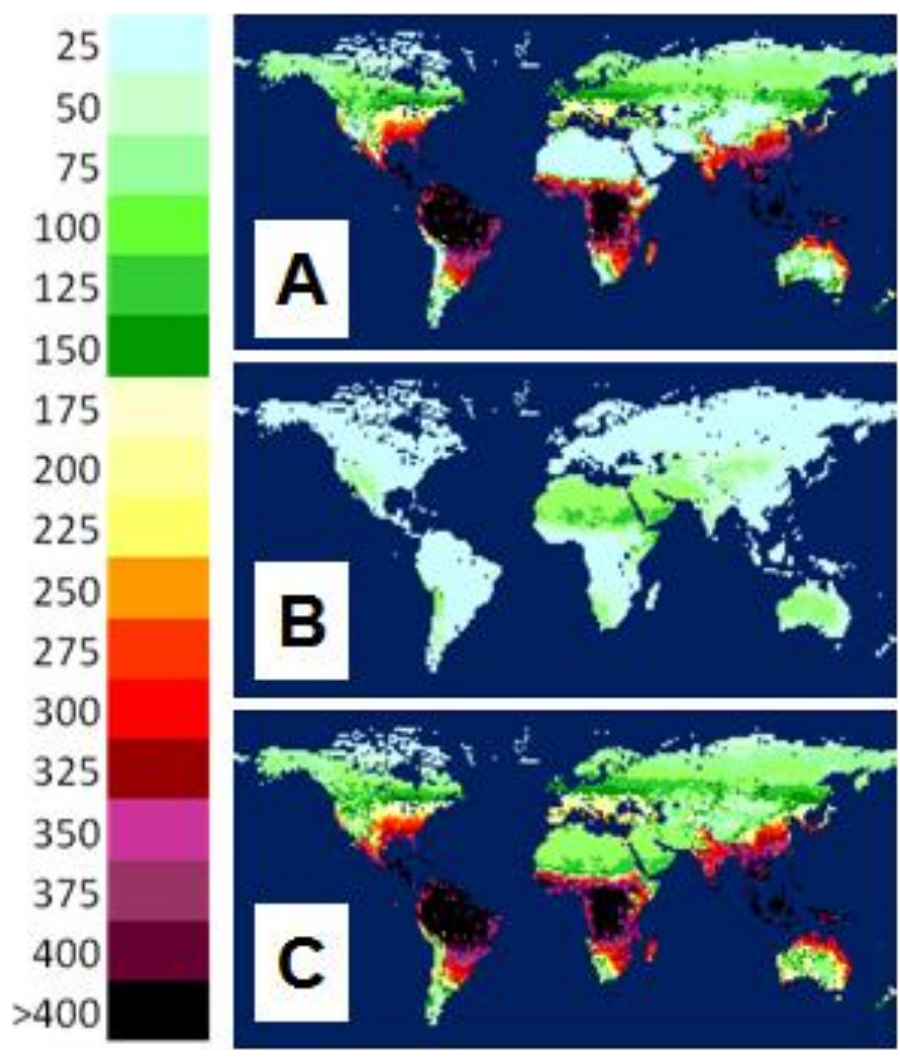

\section{BGD}

9, 8449-8473, 2012

UV-induced carbon monoxide emission from sand and living vegetation

D. Bruhn et al.

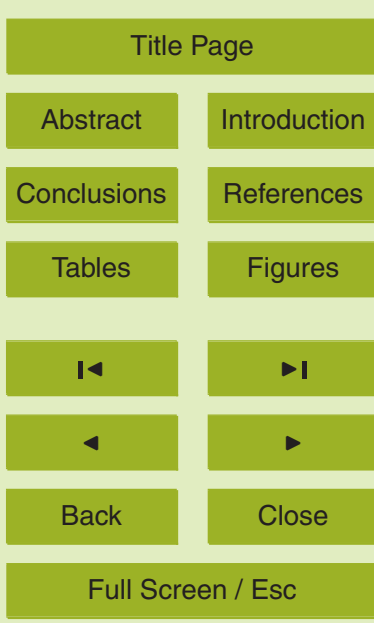

Fig. 6. World maps showing upscaled yearly $\mathrm{CO}$ emissions $\left(\mathrm{mgCO}^{-2}\right)$ from vegetation (A), sand with very low SOM (B), and sum of vegetation and sand with very low SOM (C) exposed to UV. Ice/snow covered terrestrial surfaces is partly excluded from the maps or emission is set to 0 .

Printer-friendly Version 